\title{
Analysis on Financial Capital Efficiency of Supply of Public Products in New Rural Construction
}

\author{
Xiaoyan Guo, Zhiyun Dong, Guanghui Li \\ Accounting College, Xingtai University, Xingtai, 054001, China
}

Keywords: New rural construction, Supply of public products, Financial capital efficiency

\begin{abstract}
With continuously deepening reform and opening-up, China's economy also got rapid development. In recent years, rural economy represented rapid development momentum. Moreover, peasants also harvested the achievements of the reform and opening-up policy in economic development. Now, rural income level already got great improvement, and peasants' production and living demands have basically been satisfied. However, the supply of public products and low financial capital efficiency seriously restrain good development of socialist new rural construction. On this basis, this paper mainly discusses financial capital efficiency in the supply of public products in new rural construction.
\end{abstract}

\section{Introduction}

Rapid economic development makes it activated for rural economy. Living standards of rural people also had rapid changes. With the improvement to people's living standards, people put more attention to health care, education, social security and other public products. In recent years, China has increased its financial investment into rural public products. However, there are many issues in the process of financial investment. China's public financial system is one of these issues. Our public financial policy started relatively late. In the formation process, there are also many issues mainly reflecting in low financial capital efficiency of public product supply in the process of new rural construction. Therefore, how to realize this issue and propose effective solutions becomes the main research content in this paper.

\section{Summary of Public Product Supply in New Rural Construction}

In this paper, construction of public products refers to construction of public products in rural areas. Here, construction of public products has certain differences with construction of public products in cities. At the same time, there are also many similarities. In terms of the differences, construction of public products in this paper is to meet demands of rural society; while construction of urban public products is to meet development demands of urban society. In terms of the similarities, public products in new rural construction still comply with common characteristics of public products, namely non-competitiveness of consumption, inalienability of effectiveness and non-excludability of benefit. Inalienability of effectiveness means that audiences of public products are members of new rural areas. Each social member possesses equivalent effectiveness brought by all public products instead of dividing public products into several parts and giving to some audiences. Non-competitiveness of consumption means that beneficiaries of public products (i.e. some audiences) have no right to prevent others from enjoying such products. Moreover, equivalent right should be maintained both in quality and quantity. Non-excludability of benefit indicates that the benefiting scope of public products is under certain limitations. Some individuals and manufacturers are excluded from such benefit. According to functional and demand changes of rural public products, rural public products have several categories. For the issues existing in public product supply in socialist new rural construction and relevant causes, we should enhance and improve the supply of public products in rural areas, and promote the construction of socialist new rural areas. 


\section{Primary Causes for Low Financial Capital Efficiency of Public Product Supply in New Rural Construction}

\section{Shortage of financial capital in rural areas}

With continuous improvement to living standards in rural areas, more and more peasants begin to pay attention the improvement to their quality. However, it forms a distinctive contrast with this circumstance: the supply of public products is still in a laggard stage in rural areas, which is asymmetric with rapid rural development and which cannot meet the peasants' demands for public products. There are certain historical reasons for insufficient supply capital of public products in China. After the reform and opening-up policy, the state paid most attention to urban development. As a result, the supply of rural public products is inadequate. Public construction is the orientation of public financial construction at the present stage in China. We should transform traditional production construction mode. Due to reduction to state-owned capital investment, however, investment into medicine, education and cultural undertakings is gradually reduced in the transformation process, seriously influencing public financial in Chinese rural areas. The most important reason for insufficient rural finance is ambiguity of power and duties. Both the central government and local government should be responsible for deficiency on local medicine, education, health and other undertakings. Moreover, some power and duties are overlaid for both governments. Thus, this gives an excuse for both governments to put off their responsibilities. Another reason is that there is only a small part of subsidies provided by the central government. This part of subsidies cannot meet financing gaps of local public finance. However, local government is also helpless due to its shortage in capital. This leads to the shortage in supply of rural public products. Different from cities, rural areas didn't get rapid economic development. Therefore, it is rather difficult for rural areas to raise capital for construction of public products. Even if financing is successful, most local governments are engaged in capital embezzling. As a result, financed capital cannot be used for development of public products.

\section{Supply mechanism to be perfected}

According to our national conditions and socialist routing, the supply of public products is required to be demands of peasants. Moreover, public products need to be actively provided by the government. The subject- diversified supply mechanism is established under such circumstances. The core content of this mechanism is that the peasants need to take their demands as the orientation. We can put it in this way: in the supply process of rural agricultural products, it is necessary to put the peasants' real demands in the first place and continuously understand the category, demanded degree and quantity of public products. However, the supply mechanism is not the case at the present China. For a long period of time, peasants are adaptive to thrifty and simple life. At the same time, they are used to earthy living habits. They cannot further objectively reflect their real demands. Due to communication obstacles and the issue of educational level, it decides the fact that the peasants will never actively fight for their rights to some extent. At the same time, the government, as the subject of resource supply, is difficult to raise capital. Due to mobility of the current governmental departments, many officers can make great achievements during their terms of office. However, health and education, as public products, requires huge investment and gains benefit after a long period. In a short period, it will have no outstanding performance. According to these reasons, governmental officers are not active in investment of public products in rural areas. However, governmental officers should do some practical things for the people, and help them to solve some practical issues. Therefore, it is also necessary for relevant governmental members to take actions, solve a series of issues existing in the supply process of rural public products, and make great efforts to create a better life for peasants.

\section{Difficult financing channels}

With rapid development of China's economy, the economic structure system of Chinese peasants also got continuous adjustment and upgrading. At the same time, great changes also took place in the 
peasants' demands for rural public products. The supply of public products is involved in some simple agricultural loans, exchanges, settlements, and even some complex service demands (including insurance and financial leasing). No matter from whichever aspects, it needs more financing modes into the peasants' economic structure development system. Viewed from financing conditions in China, however, most supplies of rural public products rely on the government's management and distribution. Moreover, most financial products of peasants are not subject to scientific planning or rational settlement. Comparatively speaking, it is difficult for peasants to raise capital.

\section{Improving Paths for Financial Capital Efficiency of Public Product Supply in New Rural Construction}

\section{Completion of public financial system}

According to the current status, China is still in the state of rapid economic development and fierce social contradictions. To change various conditions of the supply of agricultural products in such environment, it is necessary to further control the income conditions of the rural public financial system in China. For better control over finance and financial income, the government should achieve financial openness and transparency. Public finance cannot be known by more people unless its transparency is improved to a certain degree. At the same time, it can be supported by more people. Thus, materiality and enthusiasm of the whole government can be deployed, so as to really realize open and transparent governmental management. We need to strengthen responsibilities at various levels, and truly realize openness and transparency of public finance. Specific practices: enhance construction of electronic information project from various aspects, realize the conversion of network into a fast communication medium, and make each audience have wide access to network. Thus, relevant governmental information can be effectively communicated on the Internet, and realize active interactions with the public. At the same time, it is also convenient for the people to supervise the government's work in a better way. On the Internet, the information feedback mechanism is fast and convenient, which reduces some unnecessary troubles in the communication process. Moreover, this mechanism can also accurately express personal suggestions. Then, we definitely know that powerful social opinion is one of main factors controlling the whole social situation. These social opinions are mainly guided by newspaper, media and magazine. The government should utilize some media to interpret and timely release the information about public finance, so as to allow the people to understand in the first time the latest information about the government.

\section{Adjustment to supply mechanism}

At first, we should enhance management, further promote the establishment of rural democracy at the grassroots level, make great efforts to give full expression to various demands of rural public products, make the peasants understand the importance of public products, and provide places for the peasants to express their opinions. Secondly, we should extensively solicit the peasants' suggestions in the process of governmental decision making, so as to further improve moral quality of the peasants, and make the peasants to realize their rights and obligations and strive for their rights. Thirdly, it is necessary to continuously perfect the issue of supply in public products in rural areas. Peasants are users and beneficiaries of entire public products. Then, how peasants' internal demands can be expressed? This is an issue requiring urgent settlement by relevant governmental officers. A comparatively reasonable internal demand should be the starting point of the whole expression mechanism as well as the guarantee for the implementation of a series of policies. Fourthly, the reform to urban and rural household registration system should be implemented from beginning to end. In China, the issue of household registration policy is a historical issue as well as a serious issue. It obstructs the development of Chinese rural public products. At the same time, it also has certain effect on social stability. Therefore, we must take a series of reform measures, so as to create better 
basic living standards for the peasants, and guarantee smooth development of various governmental works.

\section{Opening-up of financing channels}

Firstly, we can start with the business of bank credit supporting agriculture in rural development bank. On the basis of guarantee for the public's basic life \& production demands, we can further increase credit aids in some sustainable development projects, such as returning the grain plots to forestry. Moreover, we can also continuously improve agricultural development, bring forth favorable economic benefits for the peasants, utilize the mode of centralized management to use some rural bank policies, and apply interest subsidy, interest and some other policies to attract commercial bank investment into agriculture. Secondly, the government can also grant agricultural banks with some rights, making agricultural development banks to effectively supervise and manage agricultural support finance. Thus, orderly development of financial institutions can be radically guaranteed. Besides, the whole rural financial system can be further improved, and economic benefits of rural financial institutions can be comprehensively improved. Thirdly, various functions of agricultural development banks should be further expanded into the construction of special capital for agriculture support. For some weak links in the construction of rural economy, the government should give great policy supports. According to local development conditions, the government can also set up some security funds, so as to guarantee rural development and supply of public products. Fourthly, China Development Bank and some other banks should assist Agricultural Development Bank in further establishing the structural system mainly of Agricultural Development Bank. Various banks should coordinate with each other, so as to make mutual efforts for rural economic development.

\section{Conclusion}

To sum up, socialist new rural construction is an important action of the present rural construction in China. Under great supports from the country, our socialist new rural construction has obtained remarkable achievements. The most obvious one is great investment into the supply of rural public products, resulting in qualitative and quantitative efficiency in rural public products. To a large extent, these achievements improved living standards and Chinese residents. Moreover, effective improvement to financial capital efficiency in the supply of public products is of great importance for promotion of new rural construction.

\section{Acknowledgments}

This paper is a special subject related to people's livelihood organized by Hebei Federation of Social Science Circles in 2014 - Research on Public Product Supply in New Rural Construction - With Xingtai as an Example (No.: 201401414; presenter: Guo Xiaoyan).

\section{References}

[1] Wang Lei, System Economic Analysis on Selection and Transition of Public Product Supply Subject - A Theoretical Analytical Framework and Its Application in China, Jinan: Shandong University, 2008: 11-12;

[2] Fang Hong, Research on Rational Determination of the Lowest Grain Purchasing Price in China, Economic Management in China, 2013, (04): 98-99;

[3] Wang Qianyuan and Li Caiyun, Analysis on Orientation of Rural Public Product Supply System from the Perspective of Public Product Demand, Journal of Hubei University of Economics, 2014, (09): 131-132; 
[4] Liu Wei, Perfection of Local Transfer Payment: Establishment of County-level Basic Financial Resource Security System, Review of Economic Research, 2010, (12): 153-154;

[5] Liao Hongfeng and Yin Xiaoliang, International Experience Reference of Rural Public Product Supply and Policy Recommendations for China, Development of Small Cities \& Towns, 2006, (01): 45-46;

[6] Wei Longbao, Wu Junjian and Shi Cheng, Research on Will Consistency of Rural Public Product Construction - Based on Empirical Analysis of "Ten Counties and One Hundred Villages" in China, Economic Theory and Business Management, 2012, (01): 145-147. 